\title{
Long term observation of mycorrhizal status and above-ground fungi fruiting body production in oak forest
}

Received: 4 April 2012; Accepted 20 July 2012

\begin{abstract}
The complex study in oak forest (Dřevíč; Czech Republic) provided unique long-term data concerning the mycorrhizal activity, fungi fructification and health status of trees in relation to elementary environmental factors.

When comparing spring and autumnal root sampling, the statistically significant difference in the nonactive mycorrhizae and dry root mass of $1 \mathrm{~mm}$ or less occurred.

The annual monitored values of fungi fructification and their differences are dependent on summer and autumn precipitation. The total annual precipitation is not of great importance.

The significant connection between defoliation and increased relative quantity of nonactive mycorrhizae and, on the contrary, reduction of the active mycorrhizae density was documented in the overall evaluation. Spring and autumn root samples provided statistically significant difference in the nonactive mycorrhizae and dry root mass of roots below $1 \mathrm{~mm}$ in diameter.

Long-term surveys are important for understanding the structure of mushroom assemblages and their biodiversity. The significant variation of the annual monitored values of fungi fructification is mostly dependent on precipitation intensity during summer and autumn and not on the total annual precipitation.

No significant relation between the mycorrhizal activity and fructification of macromycetes was found in the sense of actual maximum-minimum abundance in time. The significant variation occurs in annual values of fungi fructification, number of species and mycorrhizal distribution, what is influenced by many factors. As a most significant and influencing of these factors is the course of precipitation. The year-on-year and also spring and autumnal differences between the mycorrhizal activity which was not in correlation in time with fungi fructification, were ascertained. Since this discovery significantly predicates the status of the monitored mycorrhizal stand, we consider their actual monitoring as highly opportune and mutually completing the final general view.
\end{abstract}

Additional key words: mycorrhizal symbiosis; macromycetes; Quercus; dynamics of mycorrhizae; MultiDimensional scaling (MDS).

Addresses: V. Pešková, R. Modlinger, Forestry and Game Management Research Institute, Strnady 136, Prague 5, Czech Republic, e-mail: peskova@vulhm.cz J. Landa, Bouřilova 1104, Prague 9, Czech Republic

R. Modlinger, Czech University of Life Sciences Prague, Faculty of Forestry and Wood Sciences, Kamýcká 129, Prague 6, Czech Republic 


\section{Introduction}

Actually, a great attention is focused on research of the root systems and fungi association. Specific fungi species form mycorrhizae on the roots of woody plant species. This process is variable and reflects local conditions. Mycelium of mycorrhizal fungi connects specifically to the root interior with soil environment, that substantially increases the contact area. Therefore, mycorrhizal symbiosis is an important phenomenon when taking into consideration the tree nutrient (Mejstř́k 1988; Gryndler et al. 2004; Taylor and Alexander 2005).

For the formation of mycorrhizal symbiosis of all types it is necessary that soil contains living mycorrhizal fungi. These fungi can be present in the form of resting stage (spores) or as a symbiotically growing or vegetating mycelium (temporarily surviving without host).

The basic methodology of the assessment of forest ecosystem changes involves the visual exterior evaluation of defoliation during vegetation season. The global multiparameter methodology was created, using fungi bioindication to follow the active (ActM) and nonactive (NactM) on the roots of trees in spring and autumn season, the fungi species of mycorrhizae were not classified and the above-ground fruiting bodies of macromycetes were followed as regards their fungi diversity, frequency and abundance in individual months of the fructification period.

The distribution and correlation of the ectomycorrhizal and other fungi species is related directly to stability or in case of the disturbance to nonstability of the forest stands. This methodology of the bioindication plot evaluation by means of the field observation, quantitative evaluation of mycorrhizae and the determination of the fungi organ according to fruiting bodies, is suitable for field research and doesn't require much expenses. The methodology is reliably used in the Czech Republic since 1990s (Fellner 1990; Fellner and Pešková 1995) in the form of the assignment of forest stand aspect to particular quality (of the ectotrophic stability), especially in montane spruce, beechwood and consequently in oak wood.

When comparing the growth of woody plants from different stands, the mycorrhizal trees are better adapted to unfavorable environmental conditions and they show higher growth than those with insufficiently developed mycorrhizal symbiosis. The present results of mycorrhizal and mycological research in oak stands (Fellner and Pešková 1995; Pešková 2005) indicated mostly positive correlation of the mycorrhizal fungi species ratio (determined by fruiting bodies) relating to the values of the active mycorrhizae on the samples from soil probes). The active mycorrhizae on the majority of oak stands showed negative correla- tion when taking into consideration the trees with a strong defoliation (Fellner and Pešková 1995).

Multiple aspects of these relations stay hidden anyway, especially when considering the complex correlative of many biotic and abiotic environmental compounds.

The present results of the research suggest the consequences in diagnosis of the ratio determination of mycorrhizal macromycetes species related to the totality of species or to nonmycorrhizal species only. To a certain extent this ratio reflects the mycorrhizal situation and its lower distribution indicates the disturbance of the forest ecosystem.

In this study the mutual changes of the mycorrhizae, macromycetes and defoliation are evaluated together with the connection to the fluctuation of environmental factor on oak plots. The aim of the study was also to ascertain to what extent the methodology used in montane spruce (Fellner and Landa 2003; Pešková 2007; Pešková et al. 2011) is representative on oak plots at middle and lower altitudes. It was a case of our longest series of observation and the methodology taking up the methods standardised in the past, had to be adapted. The parameters in view are interrelated. This interrelation is difficult to identify causally in detail, what is also supported with further studies of Mosca et al. (2007), Courty et al. (2010), Richard et al. (2011).

\section{Methods}

The oak Quercus petraea study plot (called Dřevíc) was localized in the acid oak semi-natural forests of protected landscape area Krrivoklátsko. The research was carried out in the period of 1993-2002 and 2009-2010. Detailed description of the research locality: oak percentage $100 \%$, age 168 years, - tending felling was carried out on the locality to reduce the stand density to $70 \%$, altitude $430 \mathrm{~m}$ a.s.l., localization $50^{\circ} 01^{\prime} \mathrm{N}, 13^{\circ} 58^{\prime} \mathrm{E}$, surface area $2500 \mathrm{~m}^{2}$.

The Czech hydrometeorological institute (Praha-Ruzyně station $50^{\circ} 10^{\prime} \mathrm{N}, 14.27 ' \mathrm{E}$, altitude $364 \mathrm{~m}$ a.s.l.) provided us with data of the average monthly air temperature $\left({ }^{\circ} \mathrm{C}\right)$ and precipitation $(\mathrm{mm})$.

\section{Assessment of fungi species occurrence}

In the study years from May to November all macromycetes species were surveyed according to collected fruiting bodies at monthly intervals. Further, on the subplots the abundance and frequency of fruiting bodies was recorded. In all the macromycetes species found, their trophic association was established (M - mycorrhizal, SL - lignicole saprotrophic, eventually PL - lignicole saproparasitic, S - other saprotrophic, especially tericole and humicole and sporadically muscicole, fungicole or fimicole). The fungi des- 
ignation was mostly effected according to the Index Fungorum nomenclature.

\section{Root sampling, extraction, evaluation of mycorrhizae and determination of soil $\mathrm{pH}$}

With a view to studying the mycorrhizal conditions, the sampling with root probe in spring and autumn period was carried out. Sampling was done roughly at the same place (not identical), approximately in the same distance (about $1 \mathrm{~m}$ ) from the stem of the tree. The cylinder of the soil probe used for this purpose had an inner diameter of $6 \mathrm{~cm}$ and a height (depth of space sampled) of $15 \mathrm{~cm}$. The probe had saw rim for cutting roots, and inner plastic tube for stabilizing the sample. After having taken soil samples, these were placed in the refrigerator and processed.

On each plot we analyzed five root samples (Table 1) using the standard method according to Pešková and Soukup (2006). Root samples were temporarily stored in a refrigerator and then proceeded and evaluated in a laboratory. All the roots from the soil probe were prepared by hand using tweezers and then categorized. The roots of $1 \mathrm{~mm}$ in diameter or less were put into a fixing solution ( $2 \%$ glutaraldehyde) for further determination.

The roots of diameter above $1 \mathrm{~mm}$ are less usable in case of the small $(6 \mathrm{~cm})$ diameter probe since they are scattered irregularly in the soil and may not be sampled representatively. These roots were therefore used as an additional information for measuring of a total weight of root dry matter. All prepared roots were dried in the kiln ( 24 hours at temperature of $105^{\circ} \mathrm{C}$ ) and weighed with accuracy of 0,01 g.

The absolute numbers of ActM and NactM on the roots of $1 \mathrm{~mm}$ or less were one of the main monitored criteria of analyses; these mycorrhizae belong to the most adaptable and, simultaneously, to the most active components of the root systems (Mejstřik 1988; Gryndler et al. 2004).

The root segments of $5 \mathrm{~cm}$ in length and of $1 \mathrm{~mm}$ or less in diameter, including their lateral roots, were the main assessed units for the determination of numbers of mycorrhizae. In this way 20 principle root segments from each probed sample were evaluated. The numbers of individual mycorrhizal tips were determined using a binocular magnifier, magnified $40 \times$. Some active mycorrhizal tips could be wrinkled and appeared as partly withered, but they could still retain their physiological function. These problematic cases were examined on thin slices under a light microscope. According to Peterson et al. (2004) diagnostic characteristics as follows: typical tips with developed fungal mantle, Hartig net, high turgidity, lacking root hair, smooth on the surface and of lighter color - these were grouped into ActM. On the other hand, tips with significant turgor loss (wrinkled on the surface), without the fungal mantle and Hartig net were grouped into NactM.

Two parameters were used for the evaluation of the mycorrhizal association level: mycorrhizal density, and its percentage. The density of ActM and NactM was quantified as an average value of the determined mycorrhizal numbers applied to $1 \mathrm{~cm}$ of root length.

The $\mathrm{pH}$ value determined in the soil suspension was used as the main soil characteristics (ČSN ISO 10390 Soil Quality - pH Determination). The principle of this method is the surveying of the soil probes in suspension: soil - water (" $\mathrm{pH}-\mathrm{H}_{2} \mathrm{O}$ ") at volume ratio 1:5 after $5 \mathrm{~min}$ of horizontal agitation and then stabilization for a period of at least $2 \mathrm{~h}$ but not later than $24 \mathrm{~h}$. The $\mathrm{pH}$ measuring was carried out potentiometrically using $\mathrm{pH}$ meter with combined glass electrode and applicable $\mathrm{pH}$ 2-9 range.

\section{Tree defoliation}

For evaluation of a tree defoliation we used the standard method broadly used in these cases (Rõsel and Reuther 1995; UNECE 2006).

The defoliation was qualified as a percentage of lacking or damaged leaf area (at 5\% interval). The monitoring was carried out visually, and therefore the result may be burdened with errors, consequent on the researcher's subjective evaluation. The respective assessment was carried out on 50 marked trees in the period of full foliage development and ripening, so usual during the height of summer (July, August).

\section{Statistical analyses}

Statistical evaluation of all data was carried out using software Statistica 10 and NCSS 7.1. Descriptive statistics, normality tests and t-tests were used according to Hintze (2007). Technique for creating a relative positions map using classic multidimensional scaling (CMDS), was effected according to Meloun et al. (2011). The data were transferred to proximity matrix, based on similarities. Gutman-Lingoes algorithm was used for calculation of local minimum; value stress was used as a criterion for a goodness-of-fit statistic. The value under 0,05 of stress parameter is considered by Kruskal (1964) as good, the value under 0,025 as excellent.

\section{Results}

\section{Comparison of spring and autumnal root sampling}

Samplings realized in spring and autumn in the years 1998-2010 were compared in pairs. In case of ActM percentage, no statistically significant differ- 
ences were found (pair t-test; $\mathrm{P}=0.22$ ), ActM density also did not show any difference between sampling collected in spring and in autumn (pair t-test, $\mathrm{P}=$ 0.86). Concerning NactM density, the difference between sampling dates was discovered, when autumnal values of NactM density were significantly higher according to statistics (pair t-test; $\mathrm{P}<0.01$ ). Comparison of root dry weight of $1 \mathrm{~mm}$ or less showed also the difference between samplings of spring and autumn, when autumnal samplings showed statistically higher values (pair t-test, $\mathrm{P}=0.03$ ).

\section{Defoliation}

The average high defoliation of oaks was regularly monitored in the years 1993-2002 (Fig. 1). In those years with less favorable precipitation, the deterioration of health state of trees occurred (i.e. the increase of defoliation), culminating in 2000 and 2001. The decline of defoliation was documented in further monitoring (2009 and 2010). When compared to results ascertained until 2002, a considerable regeneration was documented since 2009, namely approx. by $13 \%$ and in 2009 by $21 \%$. Obviously this fact can be due to reinforced trees condition influenced by an abundance of precipitation in the winter season 2009/2010 and first half of 2010. Statistics of significant correlation between defoliation and NactM percentage was also found.

\section{Evaluation of mycorrhizae, dry root matter of $1 \mathrm{~mm}$ or less in 1993-2010}

Mycorrhizae sampled in spring 1993-2010 (Fig. 2) showed the highest median density of ActM in 1996 $\left(1.98 \mathrm{~cm}^{-1}\right)$. The lowest density was recorded in 2001 $\left(0.32 \mathrm{~cm}^{-1}\right)$. The highest NactM density was recorded in 1996 as well $\left(2.39 \mathrm{~cm}^{-1}\right)$. NactM density in spring $2002\left(0.53 \mathrm{~cm}^{-1}\right)$ was the lowest of all realized samplings. ActM percentage was highest in 2009 and 2010 (47\%); this figure was substantially lower in 2001 (22\%). Comparing values of dry root matters with roots of $1 \mathrm{~mm}$ or less from spring samplings show that the highest weight was reached in 2002 $(1.02 \mathrm{~g})$ and the lowest one in 1995 (0.15 g).

\section{Relation between mycorrhizae and environmental factors}

Total precipitation of the summer season (Prec_s) was used as a typical environmental factor. The precipitation of the winter season as well as temperature characteristics showed to be not significant (stress > 0.05). The density of ActM and NactM, NactM percentage, dry root matter $<1 \mathrm{~mm}$ and defoliation were used as a biological factor.

Statistically significant correlation between NactM $\%$ and defoliation $(r=0.80 ; \mathrm{P}<0.05)$ was found. This relation was well represented in a relative positions map (MDS - stress $<0.00001$, at iteration 478). The structure of factors in relative positions map made up two levels, that could be characterized as "health state of trees" (dimension 2) and "volume growth of roots" (dimension 1) - (Fig. 3). Precipitation in summer season affected positively the health state of trees and the development of root system, the deficit of precipitation on the contrary resulted in the grow of defoliation and the increase of NactM density or in the distribution of NactM \%. Statistically signifi-

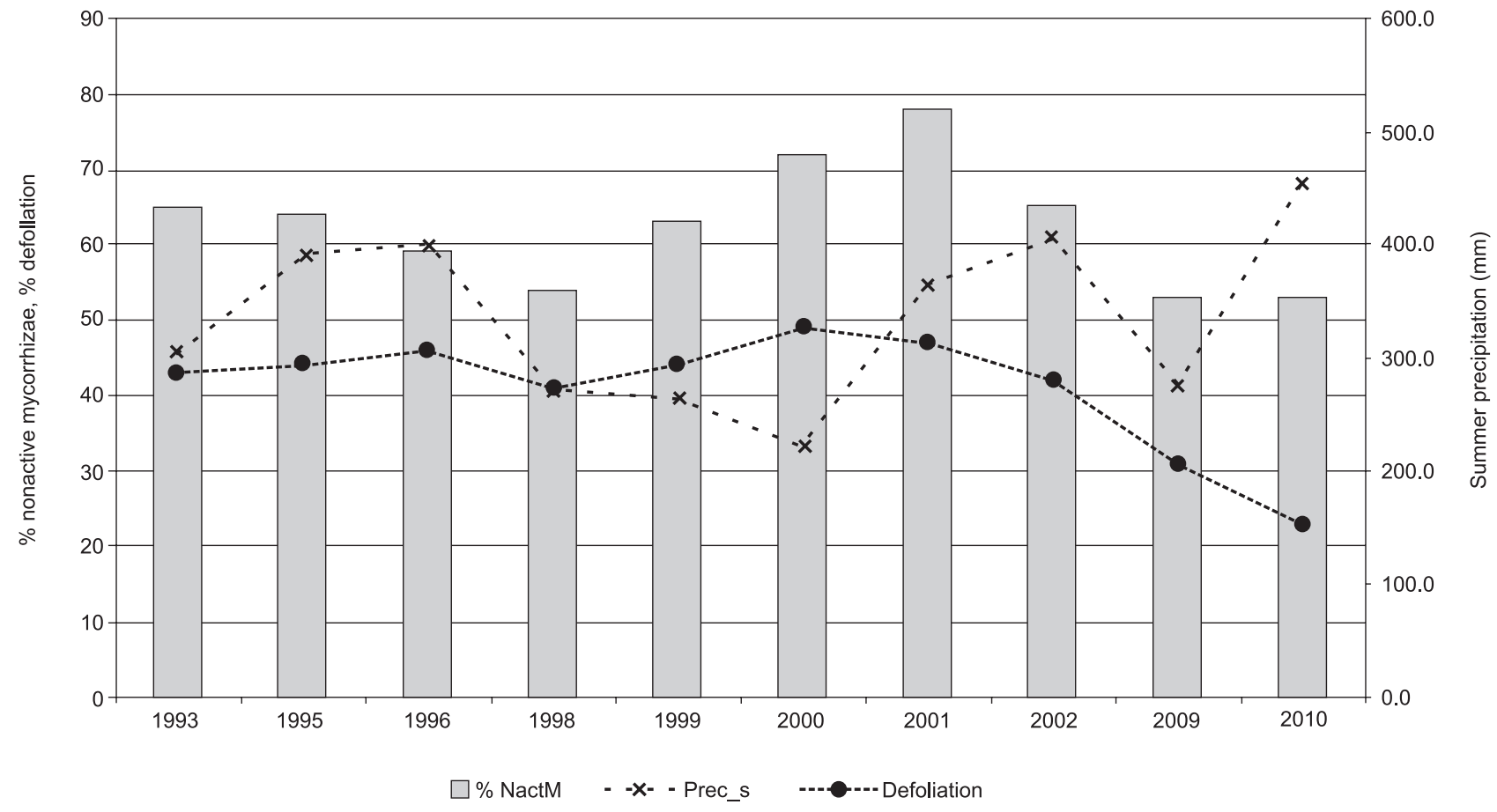

Fig. 1. Fluctuation of defoliation, nonactive mycorrhizae (NactM) percentage and summer precipitation 


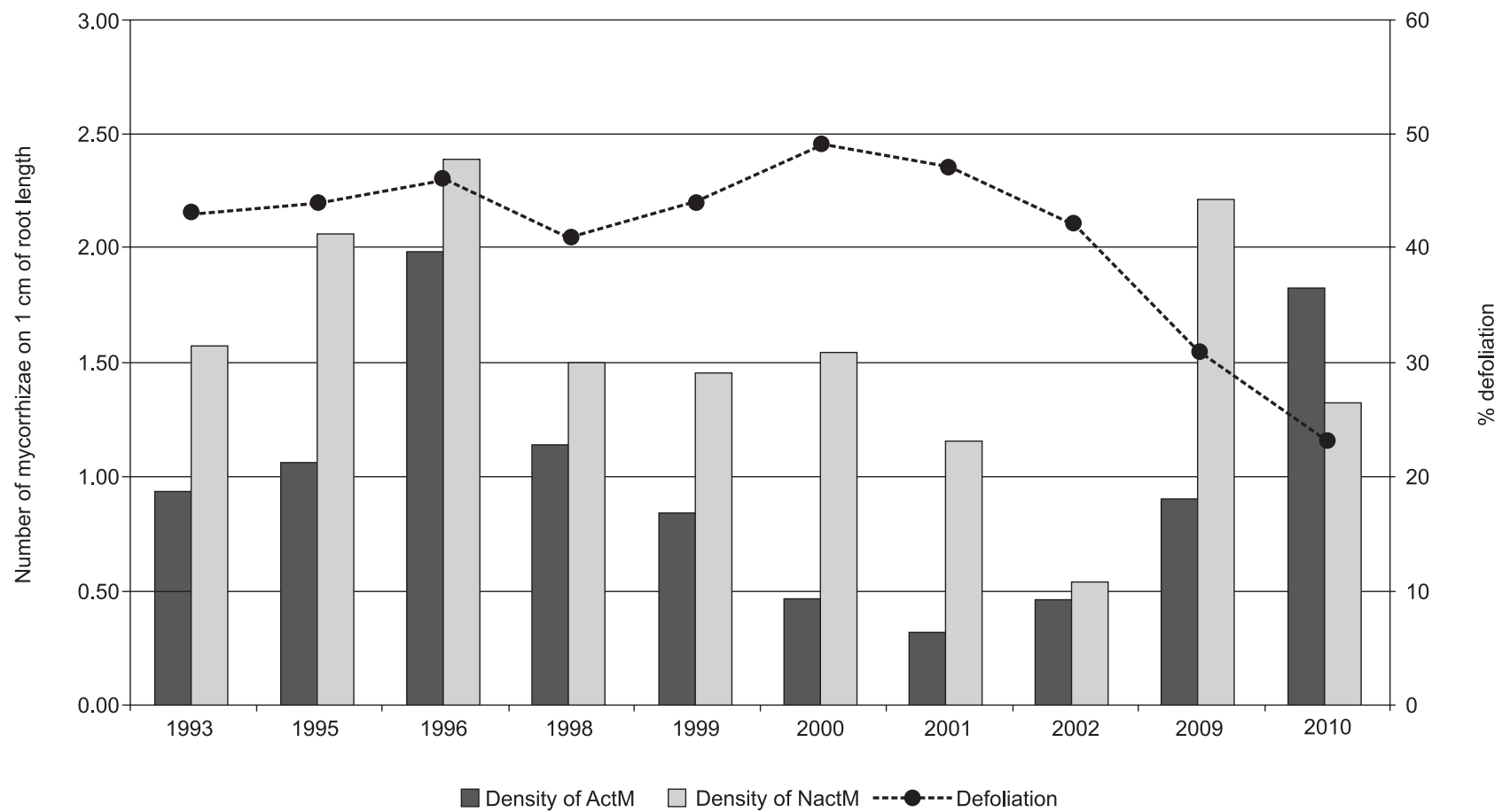

Fig. 2. Comparison of ActM/ NactM density and defoliation

cant correlation between the defoliation and ActM density $(r=0.83 ; \mathrm{P}<0.05)$ was also ascertained.

\section{Evaluation of fungi fruiting body production}

From the mycological point of view, the monitored plot (approx. $50 \times 50 \mathrm{~m}$ ) is rather rich in the distribution of multiple species of macromycetes. During 18 years in nine monitored annual seasons there occurred 222 species of macromycetes of which 91 were mycorrhizal and 131 were saprotrophic, saproparazitic, muscicole, etc. (Table 2). In the course of this long period (1993-2010) the mycorrhizal conditions and distribution of mycorrhizal fungi appeared as steady with median ratio of $41 \%$, what corresponded to low disturbance degree of the forest ectotrophic stability (cf. Fellner 1990; Fellner and Pešková 1995).

Table 1. Number of replicates, standard deviation, time of sampling

\begin{tabular}{rcrrr}
\hline \multirow{2}{*}{ Year } & \multirow{2}{*}{$\begin{array}{c}\text { Number of } \\
\text { replication }\end{array}$} & Date of & \multicolumn{2}{c}{ SD } \\
\cline { 4 - 5 } & sampling & NactM & ActM \\
\hline 1993 & 5 & 13.5. & 87.39 & 92.53 \\
1995 & 5 & 6.5. & 76.70 & 91.82 \\
1996 & 5 & 11.5. & 224.65 & 211.13 \\
1998 & 5 & 9.6. & 79.01 & 103.71 \\
1999 & 5 & 12.5. & 77.89 & 73.21 \\
2000 & 5 & 4.5. & 114.37 & 57.73 \\
2001 & 5 & 25.4. & 51.85 & 39.37 \\
2002 & 5 & 30.4. & 53.01 & 109.28 \\
2009 & 5 & 7.5. & 147.60 & 123.47 \\
2010 & 5 & 12.5. & 131.55 & 138.41 \\
\hline
\end{tabular}

The stand itself comprises largely reduced shrub layers with the absence of laying tree trunks. The lignicole fungi fructify on sparse stumps of homogenous rotting wood. This situation somewhat improves the relative percentage assessment of the mycorrhizal conditions compared with the global findings of fruiting bodies of different trophism. The situation in saprotrophic fungi of small litterfall can be described as common, often with abundance of acorns, and likewise the mycoflora of humicole and tericole macromycetes does not seem to be impoverished. The occurrence of smallest fruiting bodies is perhaps less frequent what can be caused by lower vertical diversification of the surveyed plot (higher local drying out of ground). Although this phenomenon

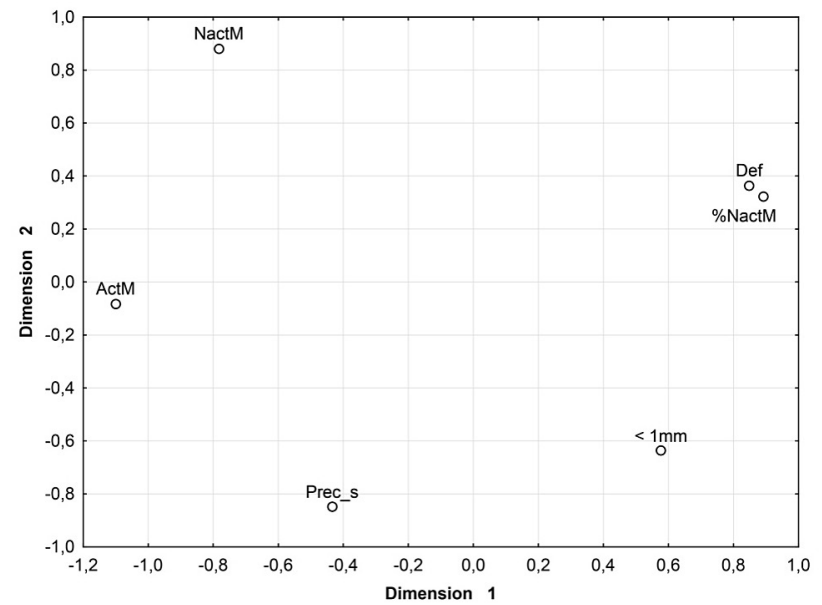

Fig. 3. Relative positions map of health state of trees (dimension 2) and volume growth of roots of $1 \mathrm{~mm}$ or less (dimension 1) 
Table 2. List of species of determined macromycetes in 1993-2010 on the plot Dřevíč

\begin{tabular}{|c|c|c|}
\hline Taxon & Troph & Pres \\
\hline Agaricus sylvicola & $S$ & 4 \\
\hline Agaricus sp. & S & 1 \\
\hline Agrocybe erebia & $S$ & 1 \\
\hline Amanita citrina & M & 6 \\
\hline Amanita fulva & M & 1 \\
\hline Amanita gemmata & M & 1 \\
\hline Amanita pantherina & M & 4 \\
\hline Amanita phalloides & M & 1 \\
\hline Amanita rubescens & M & 9 \\
\hline Amanita spissa & M & 4 \\
\hline Amanita vaginata & M & 1 \\
\hline Armillaria gallica & PL & 4 \\
\hline Ascocoryne sarcoides & SL & 1 \\
\hline Bolbitius vitellinus & $S$ & 1 \\
\hline Boletus edulis & M & 2 \\
\hline Boletus reticulatus & M & 4 \\
\hline Bovista nigrescens & $S$ & 1 \\
\hline Cantharellus cibarius & M & 2 \\
\hline Clavariadelphus pistilaris & M & 1 \\
\hline Clavulina cinerea & S & 3 \\
\hline Clavulina coralloides & S & 3 \\
\hline Clavulina rugosa & S & 1 \\
\hline Clavulinopsis cristata & S & 1 \\
\hline Clitocybe candicans & S & 2 \\
\hline Clitocybe costata & S & 2 \\
\hline Clitocybe gibba & $S$ & 3 \\
\hline Clitocybe hydrogramma & S & 2 \\
\hline Clitocybe incilis & S & 1 \\
\hline Clitocybe langei & S & 1 \\
\hline Clitocybe metachroa & S & 1 \\
\hline Clitocybe odora & S & 1 \\
\hline Clitocybe vibecina & $S$ & 1 \\
\hline Clitopilus prunulus & M & 2 \\
\hline Collybia cirrhata & S & 1 \\
\hline Coltricia perennis & S & 1 \\
\hline Conocybe pilosella & S & 1 \\
\hline Conocybe sp. & S & 5 \\
\hline Coprinus domesticus & $S$ & 2 \\
\hline Cortinarius (Seric.) sp. & M & 1 \\
\hline Cortinarius (Telam.) sp. 1 & M & 5 \\
\hline Cortinarius (Telam.) sp.2 & M & 2 \\
\hline Cortinarius anomalus & M & 2 \\
\hline Cortinarius cf.collinitus & M & 1 \\
\hline Cortinarius cotoneus & M & 2 \\
\hline Cortinarius delibutus & M & 1 \\
\hline Cortinarius elatior & M & 2 \\
\hline Cortinarius erythrinus & M & 1 \\
\hline Cortinarius glandicolor & M & 1 \\
\hline
\end{tabular}

\begin{tabular}{|c|c|c|}
\hline Taxon & Troph & Pres \\
\hline Cortinarius hinnuleus & M & 1 \\
\hline Cortinarius leucopus & M & 1 \\
\hline Cortinarius obtusus & M & 1 \\
\hline Cortinarius subsertipes & M & 2 \\
\hline Cortinarius torvus & M & 1 \\
\hline Cortinarius trivialis & M & 1 \\
\hline Craterellus cornucopioides & M & 1 \\
\hline Crepidotus mollis & SL & 1 \\
\hline Crepidotus variabilis & SL & 2 \\
\hline Cyathus striatus & SL & 2 \\
\hline Daedalea quercina & SL & 9 \\
\hline Entoloma juncinum & $S$ & 2 \\
\hline Entoloma nidorosum & M & 1 \\
\hline Exidia glandulosa & SL & 1 \\
\hline Galerina sp. (bryophile) & $S$ & 1 \\
\hline Galerina unicolor & SL & 1 \\
\hline Geastrum sp. & $S$ & 1 \\
\hline Grifola frondosa & SL & 1 \\
\hline Gymnopus acervatus & SL & 1 \\
\hline Gymnopus dryophilus & S & 5 \\
\hline Gymnopus erythropus & $S$ & 1 \\
\hline Gymnopus fusipes & S & 1 \\
\hline Gymnopus peronatus & S & 8 \\
\hline Gymnopus terginus & $S$ & 3 \\
\hline Hapalopilus nidulans & SL & 2 \\
\hline Hebeloma crustuliniforme & M & 1 \\
\hline Hebeloma longicaudum & M & 2 \\
\hline Hebeloma sp. & M & 1 \\
\hline Helvella crispa & $S$ & 1 \\
\hline Hohenbuehelia atrocoerulea & SL & 2 \\
\hline Hydnum repandum & M & 2 \\
\hline Hymenochaete rubiginosa & SL & 5 \\
\hline Hypholoma fasciculare & SL & 7 \\
\hline Hypholoma sublateritium & SL & 4 \\
\hline Hypholoma subviride & SL & 1 \\
\hline Inocybe mixtilis & M & 1 \\
\hline Inocybe rimosa & M & 1 \\
\hline Laccaria amethystina & M & 6 \\
\hline Laccaria laccata & M & 5 \\
\hline Laccaria proxima & M & 1 \\
\hline Lactarius camphoratus & M & 1 \\
\hline Lactarius decipiens & M & 1 \\
\hline Lactarius chrysorrheus & M & 4 \\
\hline Lactarius piperatus & M & 2 \\
\hline Lactarius quietus & M & 7 \\
\hline Lactarius serifluus & M & 4 \\
\hline Lactarius tabidus & M & 1 \\
\hline Lactarius vellereus & M & 4 \\
\hline Lactarius volemus & M & 1 \\
\hline Laetiporus sulpuhureus & SL & 1 \\
\hline
\end{tabular}




\begin{tabular}{|c|c|c|}
\hline Taxon & Troph & Pres \\
\hline Lepiota alba & $S$ & 1 \\
\hline Lepiota cristata & S & 2 \\
\hline Lepista flaccida & S & 1 \\
\hline Lepista gilva & S & 3 \\
\hline Lepista nebularis & S & 4 \\
\hline Lepista nuda & S & 2 \\
\hline Lepista sp. & S & 1 \\
\hline Leucocortinarius bulbiger & M & 1 \\
\hline Lycoperdon foetidum & $S$ & 1 \\
\hline Lycoperdon molle & S & 5 \\
\hline Lycoperdon perlatum & S & 6 \\
\hline Macrolepiota konradii & S & 5 \\
\hline Macrolepiota procera & S & 4 \\
\hline Marasmius lupuletorum & SL & 1 \\
\hline Marasmius rameale & SL & 1 \\
\hline Marasmius rotula & SL & 7 \\
\hline Marasmius scorodonius & SL & 1 \\
\hline Marasmius sp. & $S$ & 1 \\
\hline Megacollybia platyphylla & $S$ & 1 \\
\hline Merulius tremellosus & SL & 1 \\
\hline Micromphale perforans & S & 1 \\
\hline Mycena adonis & S & 1 \\
\hline Mycena alcalina & S & 1 \\
\hline Mycena aurantiomarginata & S & 1 \\
\hline Mycena avenacea & S & 1 \\
\hline Mycena corticola & SL & 1 \\
\hline Mycena crocata & $S$ & 1 \\
\hline Mycena epipterygia & S & 4 \\
\hline Mycena filopes & S & 1 \\
\hline Mycena flavoalba & S & 1 \\
\hline Mycena galericulata & SL & 6 \\
\hline Mycena galopus & $S$ & 1 \\
\hline Mycena inclinata & $S$ & 2 \\
\hline Mycena polygramma & SL & 2 \\
\hline Mycena pura & $S$ & 1 \\
\hline Mycena rosea & S & 3 \\
\hline Mycena sanguinolenta & S & 3 \\
\hline Mycena sp. & SL & 2 \\
\hline Mycena speirea & SL & 2 \\
\hline Mycena stylobates & S & 2 \\
\hline Mycena vitilis & S & 5 \\
\hline Mycena vulgaris & S & 1 \\
\hline Mycena zephirea & S & 3 \\
\hline Mycolachnea hemisphaerica & S & 1 \\
\hline Otidea onotica & $S$ & 4 \\
\hline Panellus stipticus & SL & 7 \\
\hline Panus rudis & SL & 2 \\
\hline Phallus impudicus & $S$ & 5 \\
\hline Phellinus ferruginosus & SL & 3 \\
\hline Pholiota lenta & SL & 6 \\
\hline
\end{tabular}

\begin{tabular}{|c|c|c|}
\hline Taxon & Troph & Pres \\
\hline Pholiota sp. & SL & 1 \\
\hline Pluteus atricapilus & SL & 1 \\
\hline Pluteus cervinus & SL & 1 \\
\hline Polyporus arcularius & SL & 3 \\
\hline Polyporus ciliatus & SL & 1 \\
\hline Psathyrella piluliformis & SL & 4 \\
\hline Psathyrella spadiceogrisea & SL & 4 \\
\hline Pseudoclitocybe cyathiformis & $S$ & 1 \\
\hline Radulomyces molare & SL & 4 \\
\hline Rhodocollybia asema & $S$ & 4 \\
\hline Rhodocollybia maculata & S & 1 \\
\hline Rhodocybe caelata & $S$ & 1 \\
\hline Rickenalla fibula & S & 3 \\
\hline Russula acetolens & M & 1 \\
\hline Russula amoenolens & M & 1 \\
\hline Russula atropurpurea & M & 2 \\
\hline Russula cf.cremeoavellanea & M & 1 \\
\hline Russula cyanoxantha & M & 7 \\
\hline Russula delica & M & 1 \\
\hline Russula emetica & M & 1 \\
\hline Russula faginea & M & 1 \\
\hline Russula fellea & M & 5 \\
\hline Russula fragilis & M & 6 \\
\hline Russula graveolens & M & 5 \\
\hline Russula grisea var. grisea & M & 3 \\
\hline Russula heterophylla & M & 2 \\
\hline Russula chloroides & M & 5 \\
\hline Russula illota & M & 1 \\
\hline Russula laurocerasi & M & 2 \\
\hline Russula lepida & M & 8 \\
\hline Russula lutea & M & 1 \\
\hline Russula melliolens & M & 2 \\
\hline Russula nigricans & M & 3 \\
\hline Russula ochroleuca & M & 2 \\
\hline Russula pectinata & M & 1 \\
\hline Russula risigalina & M & 5 \\
\hline Russula sp. & M & 1 \\
\hline Russula vesca & M & 7 \\
\hline Russula veternosa & M & 1 \\
\hline Russula virescens & M & 2 \\
\hline Russula xerampelina & M & 5 \\
\hline Setulipes androsaceus & SL & 4 \\
\hline Setulipes quercophilus & $S$ & 3 \\
\hline Schizophyllum commune & SL & 4 \\
\hline Schizopora paradoxa s.1. & SL & 4 \\
\hline Sphaerobolus stellatus & SL & 1 \\
\hline Stereum hirsutum & SL & 8 \\
\hline Stereum rameale & SL & 1 \\
\hline Stereum rugosum & SL & 1 \\
\hline Stereum gausapatum & SL & 2 \\
\hline
\end{tabular}




\begin{tabular}{lcc}
\hline \multicolumn{1}{c}{ Taxon } & Troph & Pres \\
\hline Stereum sp. & SL & 2 \\
Stereum subtomentosum & SL & 2 \\
Tapinella panuoides & SL & 1 \\
Trametes gibba & SL & 1 \\
Trametes hirsuta & SL & 2 \\
Trametes versicolor & SL & 3 \\
Tricholoma bufonium & M & 1 \\
Tricholoma saponaceum & M & 1 \\
Tricholoma sulphureum & $\mathrm{M}$ & 3 \\
Tylopilus felleus & $\mathrm{M}$ & 1 \\
Tyromyces sp. & SL & 2 \\
Tyromyces stipticus & SL & 1 \\
Vuilleminia commedens & SL & 3 \\
Xerocomus armeniacus & M & 1 \\
Xerocomus badius & M & 2 \\
Xerocomus ferrugineus & M & 2 \\
Xerocomus chrysenteron & $\mathrm{M}$ & 8 \\
Xerocomus lanatus & $\mathrm{M}$ & 2 \\
Xerocomus porosporus & $\mathrm{M}$ & 1 \\
Xerocomus pruinatus & $\mathrm{M}$ & 3 \\
Xerocomus rubellus & $\mathrm{M}$ & 1 \\
Xerocomus subtomentosus & $\mathrm{M}$ & 4 \\
Xylaria hypoxylon & $\mathrm{SL}$ & 1 \\
Xylaria polymorpha & $\mathrm{SL}$ & 1 \\
\hline
\end{tabular}

troph $=$ trophism of the fungi, pres $=$ sum of years when this taxon was recorded affects species of all trophic spectra, it can apply more to particular small saprotrophic fungi.

The findings of fungi corresponded to usually distributed species of fungi of acid oak forests of low and middle altitude. Fungi of genera Russula, Lactarius, Amanita, Boletus, Xerocomus, etc. with prevailing summer fungi fruiting body production contributed mainly to spectrum of fungi species, whereas the occurrence of genera Cortinarius, Tricholoma, Inocybe, Hebeloma with more frequent autumnal aspect, was less significant. Most frequent fungi species which were found during the whole monitored period were especially Amanita rubescens, Russula lepida, Lactarius quietus, Xerocomus chrysenteron, Gymnopus peronatus, Stereum hirsutum. Fungi species which were characteristic for acid oak forests were as follows Russula illota, $R$. laurocerasi, Lactarius chrysorreheus, Grifola frondosa, Setulipes quercophilus, Gymnopus fusipes. (e.g. Jansen 1984; Vasas 1999; O'Hanlon and Harrington 2012). On the contrary, quite a number of fungi occurred less frequently and quite exceptionally, even with one finding, only. It was not a rare case. The occurrence of different species of fungi on the oak plot is then spread out into longer time series, because most (in numbers) of determined species was monitored only in one or two years during the whole research period; on the contrary, the significant minority of fungi occurred every year. These sporadic findings comprised on the one hand rare species, as Russula melliolens, $R$. cremeoavellanea, Xerocomus armeniacus, Rhodocybe caelata, Mycena corticola, Panus rudis, on the other hand the species of relatively random occurrence., but abundant in another location.

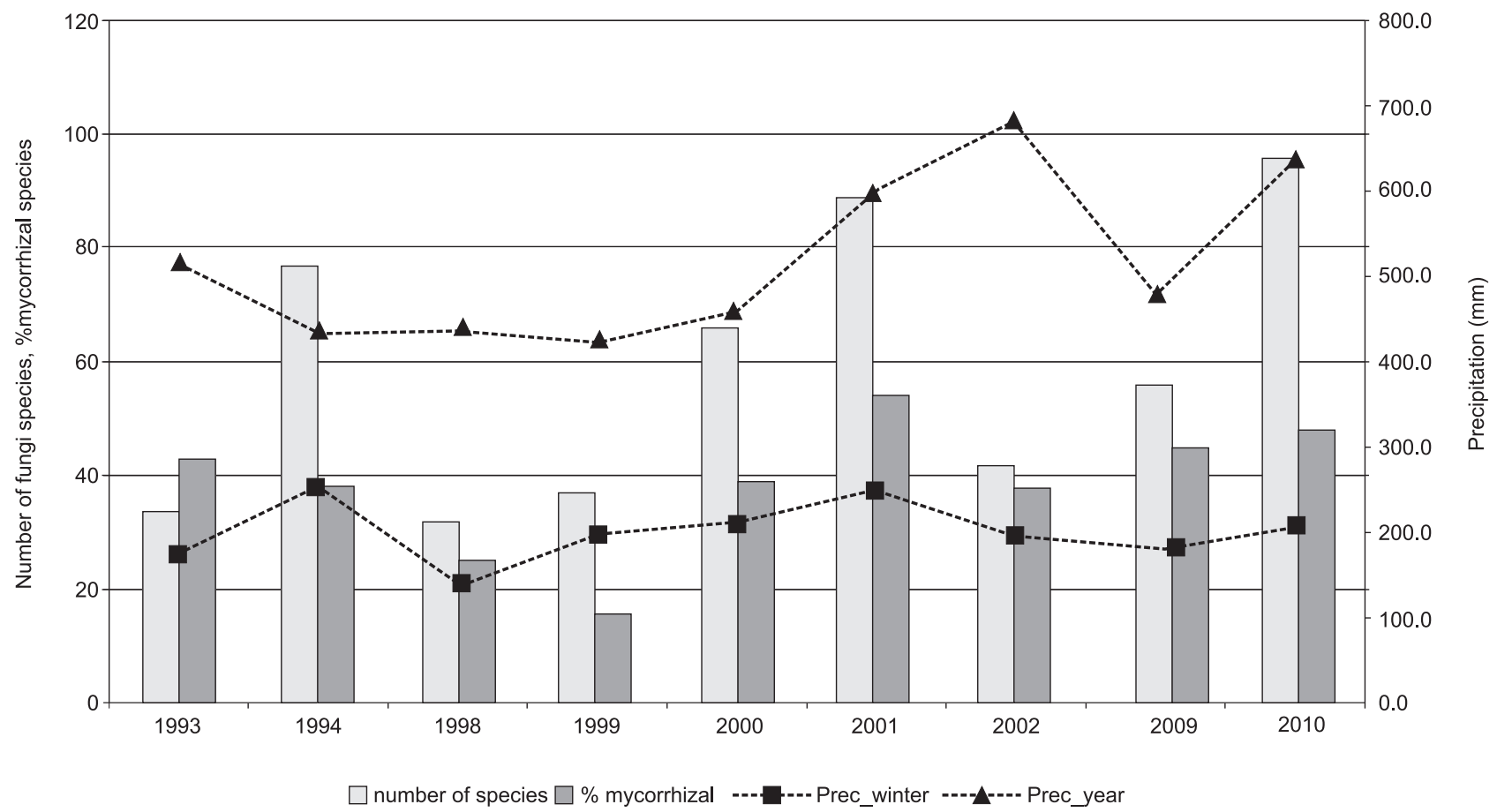

Fig. 4. Long-term fluctuation of fungi of different trophism according to their fruiting body production 
The significant variation of the annual monitored values of fungi fruiting body production is mostly dependent on precipitation intensity during summer and autumn and not on the total annual precipitation; however there appears certain positive reliance of fungi fruiting body production on amount of winter precipitation (Fig. 4).

\section{Discussion}

Data matrix that was used to complete statistical assessment, comprised different categories of information, where we assumed that they could influence the development of mycorrhizae. It must be emphasized that most factors were interrelated with mutual correlations. Ignoring simple entry abiotic factors, all the others were mainly complex correlatives.

Sampling of soil probes was surveyed with a view to register representatively the situation of root system on the examined plot with homogenous oak stand. Praxis proved that captured roots when soil probe was used, generally well represented situation of mycorrhizae on the specific plot. The exact cause of value differences is unknown, but there is a possibility of e.g. local anomalies in the chemical composition of soil, hypha focus or of some local inhibitory or activating action (either of another fungi or plant), or of temporarily unfavorable hydrological balance of specific locality etc. Therefore, a way how to eliminate the extremes described in the methodology, was used.

This is also confirmed by the work of Pešková (2011), who suggested a rather stable level of ActM density in the course of the year and a strong variation of NactM density, many times exceeding ActM. It could surprisingly indicate e.g. a significant variation of ActM life cycle. It is evident that in the course of the year and even from a long-term view, NactM density is always substantially higher, although the present works (Ferrier and Alexander 1985; Santantonio and Grace 1987; van Praag 1988) indicated its shorter "life cycle" and then theoretically lower probability of sampling capture.

The results of the roots dry weight corresponded to conclusion of Pešková (2011) indicating that the highest values were found out in October $(0.83 \mathrm{~g})$, and lowest ones on the contrary in April $(0.35 \mathrm{~g})$.

The fine roots grow mostly under appropriate humid and tempertature conditions (Santantonio and Grace 1987). In the temperate zone, one (late summer) or two (first in spring and second in autumn) periods of active roots growth were recorded (Vogt et al.1982). It could be explained by "sparse" structure of new spring roots with higher water content, whereas in autumn they lignified, gaining density with a relative water loss. In dry matter these differences became evident by diverse weight but practically in similar root volume. The question occurred whether mentioned development was typical for all the years, or whether this phenomenon in our case was more influenced by insufficient humidity in autumn (Pešková 2011).

The relation between precipitation and fungi activity like ActM, NactM density and the distribution of mycorrhizal fungi was even expressed in some other works (Azul et al. 2010). The significant role of precipitation, especially during vegetative season, also supported correlation with NactM density $(\mathrm{r}=0.70)$ in work of Pešková (2011). Contrary to very strong correlation of oaks mycorrhizae (in low altitudes) with a sum of summer precipitation, in case of the montane spruce, this relation was not confirmed. It can be simply explained by scarce precipitation at lower altitudes, what can be considered as a partly limiting factor, whilst the periodic and abundant precipitation in the mountains largely exceeds the needs and the sufficient soil humidity doesn't influence the fungi activity (Pešková 2007). Due to relatively stable climatic conditions, three years long study of the mycological and mycorrhizal status in the montane localities is sufficient (Soukup et al. 2008).

The correlation found between the percentage of NactM and defoliation supports generally accepted view of the correlation of the health status on the mycorrhizae development. A series of experiments with the artifitial inoculation of the woody species with mycorrhizal fungi suggest that the increased ActM ratio improves the above ground stamina (Szabla 2005; Kowalski 2007; Holuša et al. 2009). On the contrary, the increased NactM ratio reflects on the deteriorated health status of the tree crowns (Pešková 2005).

Dimension 1 was related to volume growth of roots (in length), when the relative decrease in mycorrhizae density (ActM, NactM) as a result of the elongation of roots (i.e. of the evaluated segments as well) occurred. However, the ratio from the total number of mycorrhizae was growing in favor of NactM percentage. The superiority of NactM probably did not represent withered ActM only (NactM would have to outlive several times), but there was most likely a mix resulting from several sources : pre-active state, withered stages and possibly initial stages, that never materialized in ActM and changed directly to "withered" state (it could be imagined as a plant that resisted "infection"). These stages could be simulated and the timing could be subsequently verified by methods known from demography.

Up to now it was ascertained that the density of mycorrhizae was especially influenced by long term local conditions with existing differences between particular localities (Pešková et al. 2011). Within one locality the percentage of ActM apparently sensitively react to immediate changes, as e.g. moisture stress, deterioration of air pollution, etc. Although it is not quite 
clear what particular stand conditions affect decisively the density of mycorrhizae, it can be recommended for comparative analyses of mycorrhizal situation and health state of forest, to use them on the stand with similar mycorrhizal density only (Fellner and Pešková 1995). The evaluated changes can also be complicated by e.g. repeated strong defoliation caused by insect feeding, that can in a certain way reduce the mycorrhizal activity in relevant years, as it was clearly documented by Last et al. (1979), when artificial defoliation of young birch was accomplished.

The long term monitoring of the fungi fruiting body production on the surveyed plot allowed for assessment: how long period was sufficient for the evaluation of fungi fruiting body production, what significant changes of forest (age change, apparent condition caused by external influence or by intentional interference) affect fungal growth; if changes in fungi fruiting body production at the end of the observed period differed strongly from the situation at the beginning, i.e. 18 years ago (respectively how they were changed during the mentioned period), how the evaluation of correlatives between the activity of subterranean mycorrhizae and fungi fruiting body production appeared in the course of monitored period, and as a whole.

The results of long term monitoring on the surveyed plots were presented by Straatsma et al. (2001); Straatsma and Krisei-Greilhuber (2003). Their long term monitoring of macromycetes in Switzerland and Austria showed similar following results compared to ours: species richness and abundance varied strongly between years and about half of the species were rare, and occurred in only one out of several years. Long-term surveys are important for understanding the structure of mushroom assemblages and their biodiversity, nevetherless we differed in numbers of surveyed plots: Czech - 1, Switzerland 5 , Austria - 13, in their size: Czech $-2500 \mathrm{~m}^{2}$, Switzerland $-300 \mathrm{~m}^{2}$, Austria - 1 ha, in total observation length: Czech -9 years, Switzerland -5 years, Austria - 13 years and in wider spectra of surveyed woody species (besides Quercus petraea also Fagus sylvatica, Picea excelsa, Pinus sylvestris). Recently, Egli (2011) assesses in summary the diversity and fruiting body production of the macromycetes as an indicator of the wood health, on the base of long term surveillance in Switzerland.

Our observation confirmed that the annual monitoring through its performing in all the months of the growing season could show up to $50 \%$ of different year-on-year results, especially due to the course of annual climate conditions. Weather conditions had to be emphasized with the absence of precipitation in autumn in particular, but also in summer time, influencing substantially the abundance of found species and also the percentage of mycorrhizal fungi. The pe- riod of three years seemed to be sufficient for establishing of the mycorrhizal situation in montane spruce forests, the period of approx. five years was considered as optimal for drying up oak forests of low and middle altitudes.

When comparing the found species of macromycetes, there was not any difference between the end of the monitored period in 2010 and the beginning in 1993. It reflected high stabilization of the local spectrum of macromycetes species on the homogenous plot wooded with acid oak forest at age of 151 to 168 years and it also reflected the absence of any fluctuation. When looking in detail on the multiple data concerning fungi fruiting body production, the final period of 2009-2010 was slightly more favorable. The correlation between the mycorrhizal activity and fungi diversity was not proved.

\section{Conclusion}

The results were obtained from the oak study plot Dřevíč (Czech Republic) in the period of 1993-2002 and 2009-2010. Data concerning the mycorrhizal activity and fungi fruiting body production in relation to elementary environmental factors.

No significant relation between the mycorrhizal activity and fungi fruiting body production was found in the sense of actual maxima-minima abundance in time. The significant variation also occurs by annual values of fungi fruiting body production number of species and mycorrhizal distribution, and is influenced by many factors. As a most significant and influencing of these factors is the course of precipitation. The year-on-year and also spring and autumnal differences between the mycorrhizal activity which was not in correlation in time with fungi fruiting body production, were ascertained. Since this discovery significantly predicates of the monitored mycorrhizal stand, we consider their actual monitoring as highly opportune and mutually completing the final general view.

The results of the long term monitoring reflect the stabilized mycorrhizal situation and homogenous plot of the acid oak forest at the age of 151-168 years, and also they show that no variation in the eventual interference and final ectotrophic stability of forest occurred during the monitored period. When comparing spring and autumnal root sampling, the statistically significant difference in the nonactive mycorrhizae and dry root mass of $1 \mathrm{~mm}$ or less occurred.

The significant connection between defoliation and increased relative quantity of nonactive mycorrhizae (\% NactM) and on the contrary reduction of the active mycorrhizae density was documented in the overall evaluation. The annual monitored values of fungi fruiting body production and their differences are dependent on summer and au- 
tumn precipitation. The total annual precipitation is not of great importance.

The drying-out oak forests of the lower and middle altitudes call for a minimum five year long comparative values regarding fungi fruiting body production, whereas the usual evaluation of the spruce montane stands considers the three year long observation as minimally sufficient.

The defoliation level belongs to one of the main indicators defining the health status of the tree. Many questions still remain unanswered regarding the dynamic relations between host -ECM. Interesting subject matters of using different up to date methods right in the field (PCR, DNA microarray, pulse-labeled C, $15 \mathrm{~N}$ enriched nitrogen, enzyme activities).

\section{Acknowledgments}

Research was supported by the Ministry of Agriculture of the Czech Republic, Project No. MZe 0002070203. We kindly thank Mr. Neil Vernon (Hobart, Tasmania) for linguistic support. The research was partly covered by project of grant agency of CULS Prague (CIGA) n. 20114314.

\section{References}

Azul A.M., Sousa J.P., Agerer R., Martín M.P., Freitas H. 2010. Land use practices and ectomycorrhizal fungal communities from oak woodlands dominated by Quercus suber L. considering drought scenarios. Mycorrhiza 20: 73-88.

Courty P.-E., Buée M., Diedhiou A.G., Frey-Klett P., Le Tacon F., Rineau F., Turpault M.-P., Uroz S., Garbaye J. 2010. The role of ectomycorrhizal communities in forest ecosystem processes: New perspectives and emerging concepts. Soil Biology and Biochemistry 42: 679-698.

Egli S. 2011. Mycorrhizal mushroom diversity and productivity - an indicator of forest health? Annals of Forest Science 68: 81-88.

Fellner R. 1990. Mycorrhizae - forming fungi as bioindicators of air pollution. Agriculture, Ecosystems and Environment 28: 115-120.

Fellner R., Landa J. 2003. Mycorrhizal revival: case study from the Giant Mts. Czech Republic. Czech Mycology 54: 193-203.

Fellner R., Pešková V. 1995. Effects of industrial pollutants on ectomycorrhizal relationships in temperate forests. Canadian Journal of Botany, Supplement 1, 73: s1310-s1315.

Ferrier R.C., Alexander I.J. 1985. Persistence under field conditions of excised fine roots and mycorrhizas of spruce. In: Ecological Interactions in Soil (eds. Fitter A.H.), Special Publication British Ecological Society, Blackwell Scientific Publications, Oxford pp. 175-179.
Gryndler M., Baláž M., Hršelová H., Jansa J., Vosátko M. 2004. Mykorhizní symbióza, o soužití hub s koøeny rostlin. [Mycorrhizal symbiosis, about coexistence of fungi with plant roots.] Academia, Praha: 366. (in Czech)

Hintze J.L. 2007. NCSS Help System. Kaysville, NCSS: 2823.

Holuša J., Pešková V., Vostrá L., Perner M. 2009. Impact of mycorrhizal inoculation on spruce seedling: comparisons of a 5-year experiment in forests infested by honey fungus. Periodicum Biologorum 111: 413-417.

Jansen A.E. 1984. Vegetation and macrofungi of acid oakwoods in the north-east of the Netherlands. Pudoc, Wageningen: 162.

Kowalski S. 2007. Ektomikoryzy. Nowe biotechnologie w polskim szkółkarstwie leśnym. Centrum Informacyjne Lasów Państwowych, Warszawa: 399 pp.

Kruskal J. 1964. Multidimensional scaling by optimizing goodness of fit to a nonmetric hypothesis. Psychometrika 29: 1-27.

Last F.T., Pelham J., Mason P.A., Ingleby K. 1979. Influence of leaves on sporophore production by fungi forming sheathing mycorrhizas with Betula spp. Nature 280: 168-169.

Mejstřík V. 1988. Mykorhizní symbiózy. [Mycorrhizal symbiosis]. Academia, Praha: 150 (in Czech).

Meloun M., Militký J. 2011. Statistical Data Analysis, A Practical Guide with 1250 Exercises and Answer key on CD, Woodhead Publishing India: 773.

Mosca E., Montecchio L., Sella L., Garbaye J. 2007. Short-term effect of removing tree competition on the ectomycorrhizal status of a declining pedunculate oak forest (Quercus robur L.). Forest Ecology and Management 244: 129-140.

O'Hanlon R., Harrington T.J. 2012. Macrofungal diversity end ecology in four Irish forest types. Fungal Ecology 5: 499-508.

Pešková V. 2005. Dynamics of oak mycorrhizas. Journal of Forest Science 51: 259-267.

Pešková V. 2007. Changes in the mycorrhizal status of some mountain spruce forests. Journal of Forest Science 53 (Special Issue): 82-89.

Pešková V. 2011. Dynamika mykorhiz v prùbìhu roku. [Year-round dynamics of mycorrhizae in oak forests]. Reports of Forest Research 56: 198-205 (in Czech).

Pešková V., Landa J., Soukup F. 2011. Findings regarding ectotrophic stability of Norway spruce forest of Krkonoše and Orlické Mts. based on mycorrhiza studies. Journal of Forest Science 57: 500-513.

Pešková V., Soukup F. 2006. Houby vázané na kořenové systémy: metodické prístupy ke studiu. Review. [Study of root fungi: methodical approach. 
Review]. Reports of Forest Research 51 (4): 279-286 (in Czech).

Pešková V., Soukup F., Fellner R., Landa J. 2007. Nové údaje o ektotrofní stabilitě krkonošských horských smrčin: srovnáně období let 1991-1995 a 2001-2005 [New data about ectothropic stability in spruce forests in the Giant Mountains: comparison of periods 1991-1995 and 2001-2005]. Opera Corcontica 44: 407-414 (in Czech).

Peterson R.L., Massicotte H.B., Melville H. 2004. Mycorrhizas: Anatomy and Cell Biology. NRC Research Press, Ottawa: 173 pp.

Richard F., Roy M., Shahin O., Sthultz Ch., Duchemin M., Joffre R., Selosse M.-A. 2011. Ectomycorrhizal communities in a Mediterranean forest ecosystem dominated by Quercus ilex: seasonal dynamics and response to drought in the surface organic horizon. Annals of Forest Science 68: $57-68$.

Rösel K., and Reuther M. 1995. Differentialdiagnostik der Schäden an Eichen in den Donauländern. GSF-Bericht, Neuherberg: 403 pp.

Santantonio D., Grace J.C. 1987. Estimating fine root production and turnover from biomass and decomosition data: a compartment-flow model. Canadian Journal of Forest Research 17: 900-908.

Soukup F., Pešková V., Landa J. 2008. Mykologické poměry na zalesněných zemědělských půdách. [Mycological conditions on afforested agricultural lands]. Reports of Forest Research 53 (4): 291-300 (in Czech).

Straatsma G., Ayer F., Egli S. 2001. Species richness, abundance, and phenology of fungal fruit bodies over 21 years in a Swiss forest plot. Mycological Research 105: 515-523.

Straatsma G., Krisai-Greilhuber I. 2003. Assemblage structure, species richness, abundance, and distribution of fungal fruitbodies in seven year plot-based survey near Vienna. Mycological Research 107: 632-640.

Szabla K. 2005. Mikoryzacja sadzonek a efekty hodowlane w uprawach. [Autoreferát disertační práce]. Dyrekcji Generalnej Lasów Państwowych Warszawa: 67.

Taylor A.F.S., Alexander I. 2005. The ectomycorrhizal symbiosis: life in the real world. Mycologist 19: 102-112.

UNECE 2006. Manual on methods and criteria for harmonized sampling, assessment, monitoring and analysis of the effects of air pollution on forests. UNECE, CLRTAP, ICP Forests.

van Praag H.J., Sougnez-Remy S., Weissen F., Carletti G. 1988. Root turnover in a beech and spruce stand of the Belgian Ardennes. Plant and Soil 105: 87-103.

Vasas G., Locsmándi C. 1999. Contributions to macrofungi of the forest along the Fekete-Körös, SE Hungary. Studia Botanica Hungarica 30: 79-86.

Vogt K.A., Grier C.C., Meier C.E., Edmonds R.L. 1982. Mycorrhizal role in net primary production and nutrient cycling in Abies amabilis ecosystem in western Washington. Ecology 63: 370-380.

Index Fungorum 2011. http://www.indexfungorum.org/Names/Names.asp (accessed 7 November 2011). 